«Технологічна освіта» та зменшити кількість годин на вивчення дисциплін суто інженерного профілю);

- в програму підготовки добавити дисципліни, спрямовані на методичну підготовку студентів до вивчення 3 учнями технікотехнологічних основ сучасного виробництва.

Отже, технологічна культура як складовий елемент професійної підготовки майбутнього вчителя трудового навчання - необхідний компонент творчої самореалізації та професійного самовдосконалення особистості майбутнього фахівця, глибокого та грамотного оволодіння основами освітньої діяльності, готовності до інновацій і новаторства.

Отже, особливості змісту формування технологічної культури майбутніх фахівців освітньої галузі «Технологія» має визначатися на засадах професійно-культурологічного підходу, який відображає особливості i функції педагогічної діяльності і спрямований на формування системи узагальнених професійно-технологічних знань, умінь і навичок, розвиток технологічного мислення.

\title{
Література
}

1. Александрова М.В. Культура та цивілізація: становлення проблематики в українській філософській думці (кінець XIX - початок XX століть): 17.00.01 - автореф. дис. канд. пед.н. - М.В. Александрова. - Харків, 2003. - 17 с.

2. Державний стандарт освітньої галузі «Технологія» // Трудова підготовка в закладах освіти. - 2003. - №1. - С. 3-6.

3. Ільченко А. Актуальні питання трудового i профільного навчання та професійної підготовки / А. Ільченко // Трудова підготовка в закладах освіти. - 2002. №1. - C. i-17.

2. Клепко С.Ф. Сума технологій для всіх Українців / С.Ф. Клепко // Імідж сучасного педагога. - 2006. - №8. - С.12-15.

3. Межуев В.М. Культура и история / В.М. Межуев. - М. : Политиздат, 1977. - 199 с. Стаття надійшла до редакції 01.06.2012 р.

\section{ФІЛОСОФСЬКО-МЕТОДОЛОГІЧНІ ПЕРЕДУМОВИ СТАНОВЛЕННЯ ТЕОРІЇ ПРОЕКТУВАННЯ ПЕДАГОГІЧНИХ СИСТЕМ}

\footnotetext{
Авраменко О.Б. Філософсько-методологічні передумови становлення теорії проектування педагогічних систем.

У статті здійснено історичний, філософсько-методологічний аналіз становлення теорії проектування педагогічних систем та системного підходу як один із головних напрямків методології спеиіального наукового пізнання, мета і завдання якого полягають у дослідженнях певних об'єктів як складних систем.

Ключові слова: проектування, педагогічне проектування, система, системний підхід, система «техносвіт - технологічна освіта».
} 
Авраменко О.Б. Философско-методологические предпосылки становления теории проектирования педагогических систем.

В статье представлен исторический, философско-методологический анализ становления теории проектирования педагогических систем и системного подхода как одного из главных направлений методологии специальных научных познаний, иель и задача которых состоят в исследованиях определенных объектов как сложных систем.

Ключевые слова: проектирования, педагогическое проектирование, система, системный подход, система «техномир - технологическое образование».

Avramenko $O$. System approach as necessities condition quality of the technological formation.

In article is presented history, philosophical-methodological analysis of the formation to theories of the designing the pedagogical systems and system approach as one of the main of the directions to methodologies of the special scientific cognitions, purpose and problem which consist in study determined object as complex systems.

Key words: designing, pedagogical designing, system, system approach, system «world technology - a technological formation».

Постановка проблеми. Стрімкий науково-технічного прогрес і зміна пріоритетів в освітній сфері та життєдіяльності суспільства висунули на передній план наукових досліджень проблему проектування педагогічних систем. Мірою дисциплінарного оформлення різних галузей знань про педагогічні системи почали з'являтися приватні теорії, які у свою чергу дозволяють постійно розширювати проблемне поле традиційної дидактики i методик викладання конкретних навчальних дисциплін, а такожщо взаємодіють акцентувати увагу педагогів і методистів на проектуванні систем, взаємодіючих із системами високого рівня організації, таких як: «особистість», «культура», «техносоціум» і «техносфера».

Проектування, що сформувалося в технічних галузях знань до середини XX століття широко розповсюдилося і в гуманітарній сфері: 3'явилися організаційне, дизайнерське, економічне, професійне, екологічне, педагогічне та інші види соціального проектування. Педагогічне проектування, як і всі зазначені вище, має технічне коріння (інженерія, архітектурне будівництво, машинобудування тощо). Однак наявні і педагогічні витоки. До них можна віднести насамперед прогнозування, зокрема дослідно-експериментальне, основи якого були закладені в 70-80-х рр. Е. Костяшкіним, В. Кутьєвим, Л. Зеленіновою та іншими дослідниками НДІ загальної педагогіки АПН СРСР. Їх розробки щодо перспектив розвитку загальноосвітньої школи, виховної роботи, змісту освіти лягли в основу створення широкомасштабних проектів, спрямованих на розв'язання сучасних проблем у педагогіці.

Становлення педагогічного проектування, його стрімкий розвиток, прагнення вчених підкреслити ті чи інші особливості й можливості застосування проекту в освіті, звісно, зумовили деякі розходження у тлумаченні проектування, визначенні його принципів, трактуванні змісту структурних елементів проектувальної діяльності. Тому будь-яке нове дослідження в цьому питанні вимагає огляду досягнутих результатів.

Аналіз досліджень проблеми. Проблеми педагогічного проектування розглядаються в працях В. Докучаєвої, А. Лігоцького, О. Коберника, T. Подобєдової, I. Коновальчука та інших. Значна кількість наукових 
досліджень, присвячених проблемам проектування, опублікована зарубіжними науковцями (В. Безрукова, В. Беспалько, Ю. Громико, Д. Джонс, Я. Дітріх, О. Заїр-Бек, У. Кілпатрік, К. Моріс, М. Поташник, О. Соломатін, Г. Щедровицький, В.Ясвін та інші). У педагогічних дослідженнях процес проектування розглядається як основний механізм здійснення та розвитку інноваційної діяльності, як особливий вид творчості, який передбачає прогнозування, моделювання та аналітичне оцінювання. Водночас, широке коло досліджень цього напрямку не вичерпує всіх питань педагогічного проектування, зокрема не систематизує питання реалізації його як основного способу проектування системи «техносвіт - технологічна освіта».

Метою статті $\epsilon$ вивчення основ процесу педагогічного проектування та визначення складових процесу проектування системи «техносвіт технологічна освіта».

Виклад основного матеріалу. Проектування в освіті - одночасно i старе, і нове явище в дидактиці та методиці навчання. Отже, закономірно необхідний аналіз історичних коренів проектування, що сягають далекого минулого науки і практики.

Ще на початку XX століття педагоги, обговорюючи проблеми реформи освіти, висували ідеї, багато в чому подібні до ідей, що лежать в основі проектування. Так, «Положення про єдину трудову школу», затверджене ВЦИКОМ 30 вересня 1918 року, передбачало широку участь органів місцевого самоврядування в шкільній справі; розвиток приватної ініціативи в освіті; створення шкільного самоврядування й організацію шкільних рад; введення зразкових навчальних програм і гнучких навчальних планів; заохочення розмаїтості підручників, навчальних посібників.

Аналіз підходів до розв'язання проблем проектування в галузі освіти дозволяє стверджувати, що низку важливих теоретичних ідей було закладено у вітчизняній педагогіці ще у 20-30-роки XX століття (А. Макаренко, С. Шацький та інші). У 60-ті роки побутувала думка про необхідність формування нової наукової дисципліни - педагогічного проектування й появи особливої спеціальності педагога-проектувальника (Г. Щедровицький). Проте проектування так і не стало предметом спеціальних досліджень, а розглядалося, переважно, як один 3 компонентів педагогічної праці, аспект різних видів діяльності в освіті, нормативна сторона організації освітнього процесу тощо.

У 1960-1970 роки одержало розвиток проектування у таких галузях діяльності, як містобудування, високотехнологічне виробництво, дизайн тощо. У цей період проектувалися не тільки речі, але і розроблялися проекти соціальних, соціально-морфологічних систем. Проектування розумілося як сила, здатна знайти рішення проблемам XX століття: організації виробництва, дозвілля й обслуговування, освіти, екології.

Аналіз практики проектування в освіті дозволяє констатувати, що в 1970-1980-і роки проектування як такого ще не було, здійснювалося конструкторська діяльність. Законодавчі акти Ради міністрів СРСР, 
«брежнєвська» конституція фіксують необхідність єдності вимог до рівня знань в освітніх закладах: школах, ПТУ, технікумах. До цього періоду віднесено створення проектів семи шкіл майбутнього, що стає джерелом проектування й експериментальної перевірки навчальних планів шкіл на початку 1980-х років, а це вже у свою чергу стало передумовою створення базового навчального плану. У середині 1980 -х багато розвинутих країн світу (Великобританія, США й ін.) почали розробляти стандарти освіти. Така робота слугувала поштовхом до появи в освітніх установах «доморослих проектувальників». Для теоретичних досліджень аналізованого періоду характерне звертання до опису планування як діяльності.

Передумовою виникнення проектування в освіті $\epsilon$ рух учителівноваторів (Ш. Амонашвілі， І. Волков， І. Іванов， С. Лисенкова， Б. Нікітін, В. Шаталов, М. Щетинін і інші), які вперше вказали на те, що проектування в освіті, багато в чому, $є$ рефлексією і спробою методичного оформлення інноваційної діяльності педагогів.

Теоретична передумова розвитку педагогічного проектування діяльність окремих науковців i наукових колективів, що розробляють проблеми освіти. 3 іменами В. Слободчікова і Н. Алексєєва пов'язані роботи із соціально-педагогічного проектування. У цей період виокремлюється специфічний напрямок - розробка методологічних основ проектування (О. Анісімов, І. Генісаретський, А. Раппопорт та інші), у яких інтегруються знання про діяльність і мислення, об'єктні знання з рефлексивними.

Виокремлення напрямку «педагогічне проектування» відбулося відносно недавно, хоча до поняття «проектування» у педагогічних роботах зверталися А. Бодалєв, В. Краєвський; виділялися проектувальні уміння i здібності педагога (З. Васильєва, С. Вершиловський, Ф. Гоноболін, І. Колесникова, Н. Кузьміна, Ю. Кулюткин, В. Максимова, В. Сластьонін та інші); у програми вчителя і керівника школи включалися проектувальні уміння (В. Кричевський, Е. Тонконога, А. Щербаков і інші); під час аналізу творчої педагогічної діяльності вказувалося на проектувальні компоненти (В. Загвязинський， В. Кан-Калик， Н. Нікандров та інші). У педагогіці на проектування як компонент керування розвитком освіти особливу увагу звертають фахівці в області прогностики і соціології освіти (І. Бєстужев, Б. Гершунський, Ф. Філіппов, Б. Юдин та інші).

Розглядаючи процеси розвитку в організаційних системах, Дж. ван Гіг на основі аналізу системного підходу визначив прикладну загальну теорію систем як метод, орієнтований на дослідження й удосконалення соціальних процесів, і виразив цей метод поняттям проектування, включаючи в це поняття такий зміст: «проблему проектування систем не можна звести до формування деякого переліку дій і їх подальшому виконанню, що забезпечує щоразу той самий результат» [3].

Лише 3 кінця 80-х років двадцятого сторіччя формування нових напрямків педагогічної науки, перехід від адміністративних до проектнопрограмних методів керування зумовили зростання інтересу до дослідження 
проектування як самостійного предмету педагогічної науки й спеціально організованої практичної діяльності. Фактично із цього періоду починають формуватися різні підходи до дослідження проектування як особливого механізму керування інноваційними процесами в освіті, як категорія дидактики, різновиду соціальної технології, що дозволяє встановити узагальнений алгоритм проектування педагогічних систем тощо.

Отже, виокремлення проектування як особливого виду педагогічної діяльності стало правомірним у той період, коли стала затребуваною інтеграція знань у єдину систему навколо розв'язання педагогічних задач. Проектування можна розділяти за характером задач, що потрібно вирішити при перетворенні педагогічних систем. Якщо необхідно розв'язання педагогічних задач різного рівня і характеру, то і йдеться про педагогічне проектування, якщо потрібне рішення задач більш високого рівня - соціального, то про соціальний. Якщо соціальне проектування організується в галузі освіти, то виокремлюється один з його напрямків - соціально-педагогічне проектування.

Педагогічне проектування - прикладний науковий напрямок педагогіки та практичної діяльності, спрямоване на розв'язання задач, суперечностей у функціонуванні систем, розвитку, перетворенні, вдосконалення, модернізації педагогічних процесів у конкретних умовах.

Задачі проектування неоднозначні, вони детерміновані низкою умов. Якщо відправною крапкою проектування є зміст, то завдання проектування ставиться як вдосконалення, раціоналізація, оптимізація; причому оптимізація проводиться за застарілими параметрами. Тим самим за такого методологічного підходу проектування розв'язує модифікаційну задачу і не $\epsilon$ дотичним до основ існуючої системи. Якщо ж відправною основою $є$ якесь уявлення про ідеальний стан системи, то задача проектування звучить як задача трансформації від належного до наявного. За подібного методологічного підходу в проектуванні проблематизуються як засоби впливу, так і критерії оцінки зміни об’єкта впливу.

Пріоритетним напрямком при формуванні теорії проектування стає пошук оптимального сполучення еволюційних змін i принципових нововведень. За еволюційного підходу до проектування виникають інновації, але вони опосередковані до основ системи, у якій виникли, а лише більш повно виявляють і використовують іiі потенціал. Подібний підхід свідомо обмежений, тому що мірою виникнення усе більш масштабних перетворень постають принципово суперечливі проектні завдання, що не усуваються 3 позицій еволюційного підходу. У галузі освіти яскравим прикладом тому $є$ досвід учителів-новаторів: їхні яскраві, новаторські знахідки, залишаючись кращими зразками еволюційного підходу, не знаходили системного перегляду освітніх концепцій.

Розкриваючи сутність проектування в освіті, Н. Алексєєв зауважує, що проектування, за найзагальнішим визначенням, $\epsilon$ ідеальне продумування i практичне втілення того, що можливо, і того, що повинно бути. Подане сутності уточнюється у визначенні Е. Крюкової, у якому педагогічне 
проектування характеризується як діяльність по визначенню умов реалізації визначеної педагогічної системи, що розглядається як сукупність знань, що описує конкретний педагогічний об'єкт, явище, процес [5]. В. Слободчиков, продовжуючи цю ідейну лінію, підкреслює, що предметом проектування $\epsilon$ створення умов (засобів, механізмів) для розвитку системи освіти в цілому, переходу іï з одного стану в інше і розкриває основні види робіт під час проектування систем:

1. Концептуалізація тієї загальної справи, що ми хочемо зробити в деякому соціокультурному просторі.

2. Програмування сукупності видів діяльності у своїй логічній і тимчасовій послідовності, що мають як основу концептуальну розробку.

3. Планування дій по реалізації проекту [7].

Проект - це поняття комплексне, яке охоплює знання різних наукових дисциплін, об'єднаних для розв'язання конкретної педагогічної задачі і сфокусованих на перетворенні конкретної системи. Сам проект також може розглядатися як система або іiі частина, що різниться від функціональної і $є$ більш досконалою для розв'язання конкретних задач. Як і будь-яка система, проект може аналізуватися з погляду його функцій, структури i 3 погляду процесу. Педагогічний проект не є незмінним та стабільним у процесі його розроблення і реалізації, тому що в такому випадку ми маємо справу 3 умовами діяльності, які постійно змінюються, тому педагогічне проектування є змінним процесом.

Розроблення проблем, пов'язаних із проектуванням, дозволяє вказати на наявність категоріальних пар «проектування і планування», «проектування i прогнозування», проектування i програмування», «проектування i моделювання», «проектування і конструювання», «проектування і втілення», «проектування і діяльність» тощо. Охарактеризуємо деякі з них.

Проектування i планування. Проектування як створення моделі бажаного майбутнього є поняттям більш вузьким у порівнянні 3 плануванням. Про планування як у методиці, так і в дидактиці зазвичай говорять тоді, коли йдеться про щось порівняно просте, що не становить істотних відкриттів і змін, про планування поточної діяльності. Коли ставиться питання про створення нової системи, процесу, отже, коли має бути виконання переважно творчої діяльності, то частіше використовується термін «проектування», при цьому планування приймає функцію однієї зі складові проектування.

Проектування i прогнозування. Успішне проектування педагогічних систем, керування ними в науці і практиці пов'язується 3 прогнозами ймовірного майбутнього, прогнозами тенденцій зміни зовнішнього середовища і самої системи. Водночас як прогнозування робить припущення про те, що може бути, проектування покликане відповісти на запитання: якою має бути система, щоб їі функціонування давало високо якісні результати. У теорії дидактики доведено, що проектування повинне спиратися на наявні прогнози ситуацій, містити в собі елементи й етапи прогнозування, але воно не може бути ототожнено прогнозуванню як діяльності. 
Проектування i моделювання. Проектування i конструювання. Проектування i втілення. При розгляді проектування як спеціально організованої людської діяльності стає ясно, що моделювання є тільки частиною проектування, хоча і украй важливої. Проектування у вузькому змісті, що припускає створення ідеальної моделі нової системи часто приймається як синонім моделювання. Результати аналізу практики вказують на те, що між проектуванням і конструюванням існує досить умовне розходження, що має відносний характер. Конструювання - це створення на основі проекту реальних педагогічних систем. Результати проектування педагогічних систем втілені в практиці з тією або іншою мірою успішності, точності, 3 великими або меншими перекручуваннями $\mathrm{i}$ відступами від проекту.

Отже, можна сказати, що педагогічне проектування тісно пов'язане 3 такою категорією, як «педагогічна система», яку ми ототожнюємо із системою «техносвіт - технологічна освіта».

Структура будь-якої педагогічної системи $\epsilon$ взаємозалежною сукупністю інваріантних елементів: 1 - учні; 2 - мета навчання і виховання; 3 - зміст навчання і виховання; 4 - процеси навчання і виховання; 5 вчителі; 6 - організаційні форми навчання і виховання [2].

Виходячи 3 аналізу теоретичних джерел 3 проблеми проектування педагогічних систем, можна сформулювати такі висновки:

- проектування - термін, що досить широко використовується в сучасній соціальній та педагогічній літературі й відображає сучасну ситуацію перетворення педагогічних систем;

- педагогічне проектування $\epsilon$ напрямком теорії та методики педагогіки і практичної діяльності дослідників, орієнтованої на визначення, обгрунтування, експертизу i надання способів рішень сучасних задач педагогічної практики;

- педагогічне проектування можна розглядати як структурні i процесуальні характеристики діяльності, спрямованої на розв'язання різних проблем педагогіки;

- об'єктом педагогічного проектування є педагогічні системи різного рівня і характеру або їх структурні компоненти, що також досліджуються у взаємозв'язку із системою в цілому;

- педагогічне проектування - продуктивна діяльність, результатом якої є проект і програма його реалізації в практиці, а також результати, що мають місце під час реалізації проекту [8].

Отже, аналізуючи проблему проектування в педагогіці, ми виокремили такі основні категорії, з якими надалі будемо оперувати - «проектування», «система», «моделювання».

Розкриття сутнісних питань теорії проектування педагогічних систем починається з характеристики об'єкта проектування - «педагогічної системи».

Ми підтримуємо В. Ченобитова в тому, що [10], технологія проектування систем - це спосіб оволодіння освітнім середовищем і його 
перетворення, що (середовище) характеризується необхідністю діяти в умовах неповноти інформації, вибору альтернативних способів діяльності, системного розгляду об'єктів і процесів, перманентних проблемних ситуацій, рольового поводження, колективної творчої діяльності.

Загалом, під системою традиційно розуміється визначена сукупність взаємозалежних елементів. А. Уємов поняття «система» визначає не як порожню множину елементів, а як систему, що має такі найбільш істотні характерні особливості: цілісність, структурність, взаємозалежність системи і середовища, ієрархічність [9].

У низці понять, за допомогою яких подається характеристика будьякої системи, можна виокремити: елементи системи, процес перетворення елементів, характеристику зв'язків між елементами, підсистеми, структуру, границі системи, контакти з довкіллям, призначення і функції, що, у свою чергу, визначаються цілями і задачами.

«Педагогічна система - це цілісна єдність усіх чинників, що сприяють досягненню поставлених цілей розвитку людини» [1].

Під поняттям «педагогічна система» мається на увазі складна сукупність взаємодіючих елементів, окремих систем i зв'язків, що забезпечують можливість впливати на перебіг педагогічного процесу, тобто керувати ним. Теоретичний аналіз літератури з проблеми дозволив з'ясувати, що до переліку основних характеристик педагогічної системи відносяться:

- розуміння сутності, мети і завдань навчання та виховання;

- структура системи навчальних закладів і наступність в освіті;

- основні ідеї і зміст освіти;

- міжпредметні зв’язки, наступність і взаємодія; навчальні програми, принципи їх побудови й основний зміст;

- позашкільна система навчальних закладів і зміст їхньої роботи;

- передові дидактичні системи [4].

Проектування будь-якої педагогічної системи, зокрема i системи «техносвіт - технологічна освіта», організовується з урахуванням взаємодії іiі різних компонентів не ізольовано, а в єдності один 3 одним і зовнішнім середовищем. Системність проектування дозволяє обгрунтовувати, припускати і досліджувати важливу особливість розвитку систем, на яку звертають увагу вчені під час розроблення системних підходів. Розвиток складної системи відбувається в напрямку, обумовленим іiі внутрішньою структурою, їй не можна нав'язати шлях розвитку, можна лише сприяти або перешкоджати їі власним тенденціям. У зв'язку з цим вплив на систему парадоксальний за ефектом - сильний вплив може не зробити нікого ефекту або виявитися деструктивними, а слабкий, але резонансний (відповідній структурі, тенденціям розвитку системи) може бути надзвичайно ефективний.

Педагогічне проектування повинно опиратись на принципи, які випливають із загальнопедагогічних принципів гуманізації сучасної освіти та теорії проектування. Тому принципи педагогічного проектування мають такий зміст: принцип людських пріоритетів як принцип орієнтації на людину - 
учасника підсистем, процесів або ситуацій - $є$ головним; принцип саморозвитку проектованих систем, процесів, ситуацій означає створення їх динамічними, гнучкими, здатними по ходу реалізації до змін, перебудови, ускладнення або спрощення [4].

Із системністю в проектуванні пов'язані єдність і розмаїтість компонентів системи, їхня додатковість, взаємозв'язок, взаємовплив. Принцип функціональної доповненості, сформульований у теорії систем як принцип гармонії розвитку структури системи, дозволяє погоджувати й інтегрувати взаємодію різних компонентів системи на основі виокремлення функцій усієї системи і функцій кожного 3 його елементів. Для цього виконується структурний аналіз системи.

За педагогічного проектування виникає проблема стійкості системи, збереження іiі основних педагогічних функцій, гармонійності в їхній дії, що викликає необхідність переходу від виміру в розвитку (досягнуте - не досягнуте) до його оцінювання (ефективно - неефективно; добре - погано). В іншому випадку, система може змінювати свої основні цільові педагогічні функції. Тому, незважаючи на творчий характер проектування, його суб'єктивність, важлива реалізація принципу нормованості у розвитку системи, що означає не обмеження в розвитку, а обмеження в зміні ведучих функцій системи і не порушення загальної гармонії в структурі.

Результатом проектування є педагогічний проект, у нашому випадку система «техносвіт - технологічна освіта», функціональна специфіка якого залежить від таких умов: стану середовища, особливостей суб'єктів, зайнятих підготовкою конкретного проекту, функціональних зв'язків між елементами проекту, можливостей його ефективного використання, очікуваних результатів.

Отже, розроблення наукового апарату системного підходу, його використання для обгрунтування понять і категорій педагогіки привели до визначення сутності, структури й функцій педагогічної системи. В роботі [6] виділені такі компоненти системи:

- потреби суспільства у підготовці кадрів;

- інформація, що є предметом засвоєння в процесі навчання;

- засоби, методи, форми педагогічного впливу для досягнення мети;

- контингент людей, що мають необхідність у певній підготовці;

- педагоги, що володіють необхідною інформацією, а також засобами спілкування в процесі навчання й виховання.

Висновки. Сутність проектування системи полягає в конструюванні бажаних станів майбутнього. Проектувальник вибудовує моделі, виходячи 3 концептуального розуміння об'єкта, який конструюють, і бачення наукових, просвітніх, практичних проблем діяльності. Проект спрямовано на досягнення соціальної чи особистісно значимої мети й орієнтований на використання в умовах конкретного місця, часу і наявних у розпорядженні ресурсів. 


\section{Література}

1. Безрукова В.С. Педагогика. Проективная педагогика: [учеб. пособ. для инженерно-пед. инстутов и индустр.-пед. техникумов] / В.С. Безрукова. - Екатеринбург : Деловая книга, 1996. - 344 с.

2. Беспалько В.П. Слагаемые педагогической технологии / В.П. Беспалько. - М. : Педагогика, 1989. - 192 с.

3. Дж. ван Гиг «Прикладная общая теория систем» / Дж. ван Гиг: [пер. с англ.]. М. : Мир, 1981. -733 с.

4. Заир-Бек Е.С. Теоретические основы обучения педагогическому проектированию: дисс. ... докт. пед. наук / Е.С. Заир-Бек. - С.-Пб., 1995. - 410 с.

5. Крюкова Е.А. Введение в социально-педагогическое проектирование: [учеб. пособ. к спецкурсу; науч. ред. Н.К. Сергеев] /Е.А. Крюкова. - Волгоград: Перемена, 1998. - С. 57.

6. Методы системного педагогического исследования: [учеб. пособие / под ред. Н.В. Кузьминой]. - Л. : Ленинград. гос. ун-т, 1980. - 172 с.

7. Слободчиков В.И. Проблемы научного обеспечения инновационной деятельности в образовании / В.И. Слободчиков. - Киров, 2003. - 152 с.

8. Смыковская Т.К. Теоретико-методологические основы проектирования методической системы учителя математики и информатики : дис. ... д-ра пед. наук: 13.00 .02 / Т.К. Смыковская. - М., 2000. - 383 с.

9. Уемов А.И. Системный подход и общая теория систем / А.И. Уемов. - М. : Мысль, 1978. - 272 с.

10. Ченобытов В.А. Педагогическое проектирование как акмеологическая технология педагогического образования: [электронный ресурс]. - Режим доступа. URL: // http:akmeo.rus.net/index/php?id=127.

Стаття надійшла до редакції 01.06.2012 p.

УДК 371.321

А. М. Гедзик, кандидат пед. наук, доиент,

Уманський ДПУ імені Павла Тичини

\section{ВИКОРИСТАННЯ ТВОРЧИХ ГРАФІЧНИХ ЗАДАЧ У ПРОЦЕСІ ПІДГОТОВКИ МАЙБУТНІХ УЧИТЕЛІВ ТЕХНОЛОГІЙ ДО ПРОЕКТНОЇ ДІЯЛЬНОСТІ}

Гедзик А. М. Використання творчих графічних задач у прочесі підготовки майбутніх учителів технологій до проектної діяльності.

У статті проаналізовано можливості оптимізації професійної підготовки майбутніх учителів технологій до проектної діяльності засобами творчих графічних задач, які повинні базуватись на принципах, покладено в основу концепщіі системи активізації навчання $i$ які охоплюють основні аспекти навчально-виховного процесу.

Ключові слова: професійно-графічна підготовка, проектна діяльність, конструкторські знання, оптимізачія навчального прочесу, типологія задач.

Гедзык А.Н. Использование творческих графических задач в прочессе подготовки будущих учителей технологий к проектной деятельности.

В статье проанализированы возможности оптимизации профессиональной подготовки будущих учителей технологий к проектной деятельности средствами творческих графических задач, которые долюжны базироваться на принципах, что положенны в основу концепиии системы активизации обучения и которые охватывают основные аспекты учебновоспитательного процесса. 